\title{
An Analysis of Inventory Attributes in Leagile Supply Chain: Cause and Effect Analysis
}

\author{
Mukesh Kumar \\ Department of Mechanical Engineering \\ National Institute of Technology Kurukshetra, Kurukshetra, India \\ Corresponding author: mk10@nitkkr.ac.in \\ Dixit Garg \\ Department of Mechanical Engineering \\ National Institute of Technology Kurukshetra, Kurukshetra, India \\ Ashish Agarwal \\ Mechanical Engineering Department, \\ Indira Gandhi National Open University (IGNOU), New Delhi, India
}

(Received November 24, 2018; Accepted April 5, 2019)

\begin{abstract}
In the recent era, managing a supply chain efficiency is the necessity of any business due to shorter product life cycle and market penetration order uncertainty. With the increased competition globally, organizations need to be more efficient and responsive. This situation drives attention to the concept of Leagile Supply Chain (LASC). Therefore, more attention to Lean and agile inventory attributes are advocated as the foundation to sustain competitive LASC. Trade-off between the lean and agile supply chain inventory attributes and interrelationship. Upstream lean practise based on push system and downstream agile practices based on pull system. In this paper, the cause and effect analysis is to measure the influence of integrated LASC inventory attributes on the Supply Chain Performance (SCP). From the managerial viewpoint, cause and effect diagram provides the proactive understanding to positive and negative inventory attributes affects SCP.
\end{abstract}

Keywords- Lean, Agile, Leagile Supply Chain (LASC), Supply Chain Performance (SCP).

\section{Introduction}

The recent decade of globalization, organizations are more intended becoming aware of gaining the strategic reputation by use of holistic perspective approach on competitiveness ingredient to maintain position sustainability in the respective field (Sangari et al., 2015). In the presence of philosophy, commodities ought to be produced and distributed of the total cost of the systemwide (Routroy and Kodali, 2005). Tannous and Yoon (2018) reveal that the quality of global supply chain management (GSCM) hinders various areas of vertical and horizontal operations from start to end of the chain. This help to create synergy among SC stakeholders and the environmental affords social, environment and economical sustainability.

Various definitions of lean can be found from literature, but the principle remains the same i.e. waste elimination and cost minimization. Wu and Wee (2009) reported that how the lean production is combined with the 'zero inventory' and 'just in time' (JIT) approach. According to Competitive Strategy (CS), Lean Supply Chain (LSC) is suggested when cost is the priority while Agile Supply Chain (ASC) is suggested when speed is the priority (Mason-Jones and Towill, 1999). The lean concept is preferred, when the demand is stable, predictable and has less variety 
International Journal of Mathematical, Engineering and Management Sciences

Vol. 4, No. 4, 870-881, 2019

https://dx.doi.org/10.33889/IJMEMS.2019.4.4-069

of products while agile supply chain is preferred when the demand is volatile with high variety of products (Agarwal et al., 2007). There is a requirement to adopt a hybrid strategy (Christopher and Towill, 2000). According to Table A1 of Annexure-A), the migratory model and early 1980s the market winner was quality and was attained within the lean internal process scenario (Womack et al., 1990).

In a recent example, Dell has the customised LASC. Furthermore, restructuring the supply chain front end, Dell suppliers exactly decide what the individual customer selects. The lead time is maximum seven days for pulling off the essential for sub-assemblies, after finalising the PC, and additional packing and distribution to the retail customer. Agility is a key source of business capability that incorporates organization structure, information system, logistic processes and existing mind-sets (Katayama and Bennett, 1999; Power et al., 2001).

With the increased competition globally, organizations need to be more efficient and responsive. This situation drives attention to the idea of Leagile Supply Chain (LASC). The LASC enables the upstream part and downstream parts are consequently cost-effective and higher service level in the volatile marketplace. The grey theory implementation for modelling preference criteria for decision makers of two dimensions that involves flexibility and sensitivity of the market.

\subsection{Objectives of the Work}

- To examines the trade - off between lean and agile inventory attributes and interrelations.

- To build the connection between lean and agile supply chain attributes (SCAs)

Section 2 discusses the related literature review. Section 3 covers the trade-off between lean and agile supply chain inventory attributes and inter-relationship. Section 4 provides combined lean and agile inventory attributes practices vs. supply chain attributes. Finally, concluding remarks are given with the scope of future research.

\section{Literature Review}

Khalili and Alinezhad (2018) reveal that investigate green supply chain efficiency by using DEA (Data Envelopment Analysis) which is based on MPI (Maximum Productivity Index) according to input/output indicators of balanced Scorecard model and accordingly providing some rules using the decision tree. The result indicates that the proposed model had a higher degree of accuracy and interpretations in evaluating performance compared models and help managers to the better decision of automotive parts manufacturing firms. According to Qamar et al. (2018) explored that the modern manufacturing industries are endurance of transit phase in their SC strategy. The study focuses on lean, agile and leagile in the Supply Chain Strategy (SCS). The success of supply of an organization in the competitive market demands on the management and improve the SC. The performance metric of case SC has been modelled and dominant SC paradigms have been evaluated. Using the ANP and conceptual model for LASC metrics was developed and SC performance weight index score leagile has been achieved in SCS. Recent environment intense cutting edge of market competitions and sophisticated IT business tools more necessity for the organization to match specific individual customers by appropriate strive SC strategy (Weinstein, 2018).

Pavlis et al. (2018) developed a relationship b/w dimension of supply management performance and the components of the cash conversion cycle. The model proposed and hypotheses were tested using data from SMEs operating in Greece. The results will be helpful in better 
International Journal of Mathematical, Engineering and Management Sciences

Vol. 4, No. 4, 870-881, 2019

https://dx.doi.org/10.33889/IJMEMS.2019.4.4-069

understanding the impact of supply management practices and the performance of supply management by analyzing the balance sheets and profits-loss statements.

Pakdil and Leonard (2014) explained the managing concept based on lean principle enables organization to the obtained higher level of efficiency, competitiveness based on lower cost criteria, with the more frequent level of productivity, faster speed of delivery, minimum stock levels and optimum quality. Leanness should be developed in phase in an organization develop environment be innovative and proper supportive. It should be achieve the goal of management commitment (Wyton and Payne, 2014).

According to Vinodh and Aravindraj (2013) reveals that continuous changing business environment, manufacturing firm's challenges to survive by existing to dynamic demand of modern customer desired. According to lean and agile principle has based on zero inventory and safety inventory required for volatile market conditions. The performance evaluations of the lean and agile concept as well as leagility SCs using fuzzy logic approaches.

\section{The Trade-off between Lean and Agile Supply Chain inventory Attributes and Inter-Relationship}

While implementation of lean and agile practices, the balance between these two must be ensured and also it should consider the SC strategy as defined. Understanding the relationship between supply chain characteristics and key performance is very important. The illustrated Table A2 (Annexure- A) clearly the relation among the lean inventory attributes and the SC performance.

The trade-off between lean -agile SCM paradigms must be compulsory to decide surplus or strategic stocking point for most of the companies as well as more sustainable and efficient supply chain. According to Azevedo and Machado (2009); Azevedo et al. (2010); Carvalho et al. (2010), the management of lean and agile practices have a good and bad impact on other. Figure 1 shows a clear view of trade off $b / w$ lean and agile supply chain inventory attributes.

The principle difference between inventory attributes is the purpose: the lean supply chain seeks to waste minimization; the agile supply chain is covered on quick responding to Market changes". To evaluate the contribution of lean and agile inventory attributes impact on the SCP, there is a need to develop a relationship among the SC characteristics changed by the lean and agile attributes and the relation with performance indicators. For a better understanding of these relationships, the cause-effect diagram was developed. 
International Journal of Mathematical, Engineering and Management Sciences

Vol. 4, No. 4, 870-881, 2019

https://dx.doi.org/10.33889/IJMEMS.2019.4.4-069

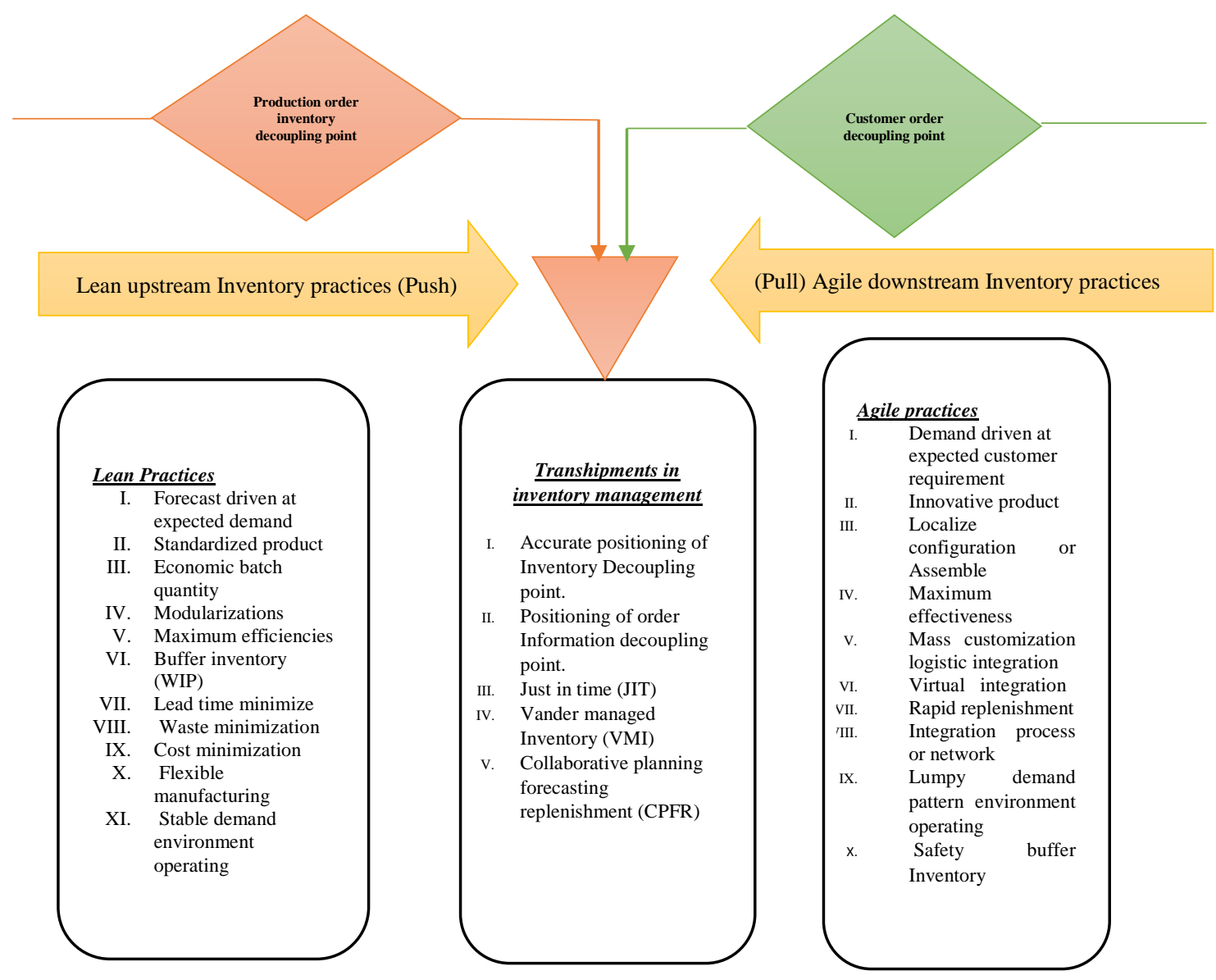

Figure 1 . Trade off $b / w$ lean and agile supply chain in inventory attributes

\subsection{Lean Inventory Attributes vs Supply Chain Attributes}

The linkage between lean inventory attributes and SCP have depicted in Figure 2.

The relation between the lean inventories attributes and supply chain performance will result in better understanding, with the following interpretations.

- Inventory level Minimization: The performance of supply chain affected by negatively in inventory level minimization. Higher inventory level minimization stimulates a lower inventory level.

- Convention alliances (trust, profit sharing, openness): The performance of supply chain affected by positively in relation to trust, negotiation and profit sharing of conventional alliances in the lean supply chains.

- Information frequency: The performance of supply chain improved by the flow of information frequency at information flow across the network.

- JIT: JIT implementation results in increased replenishment frequency. 
International Journal of Mathematical, Engineering and Management Sciences

Vol. 4, No. 4, 870-881, 2019

https://dx.doi.org/10.33889/IJMEMS.2019.4.4-069

- Resource utilization: The implementation of lean practices is characterised by higher supply chain resource utilization, decreasing the supply chain capacity excess.

- Lead time reduction: The length of the lead time is an important factor of Production and transportation Lead Times (PTLT), to reduce the lead time affects negatively to the PTLT.

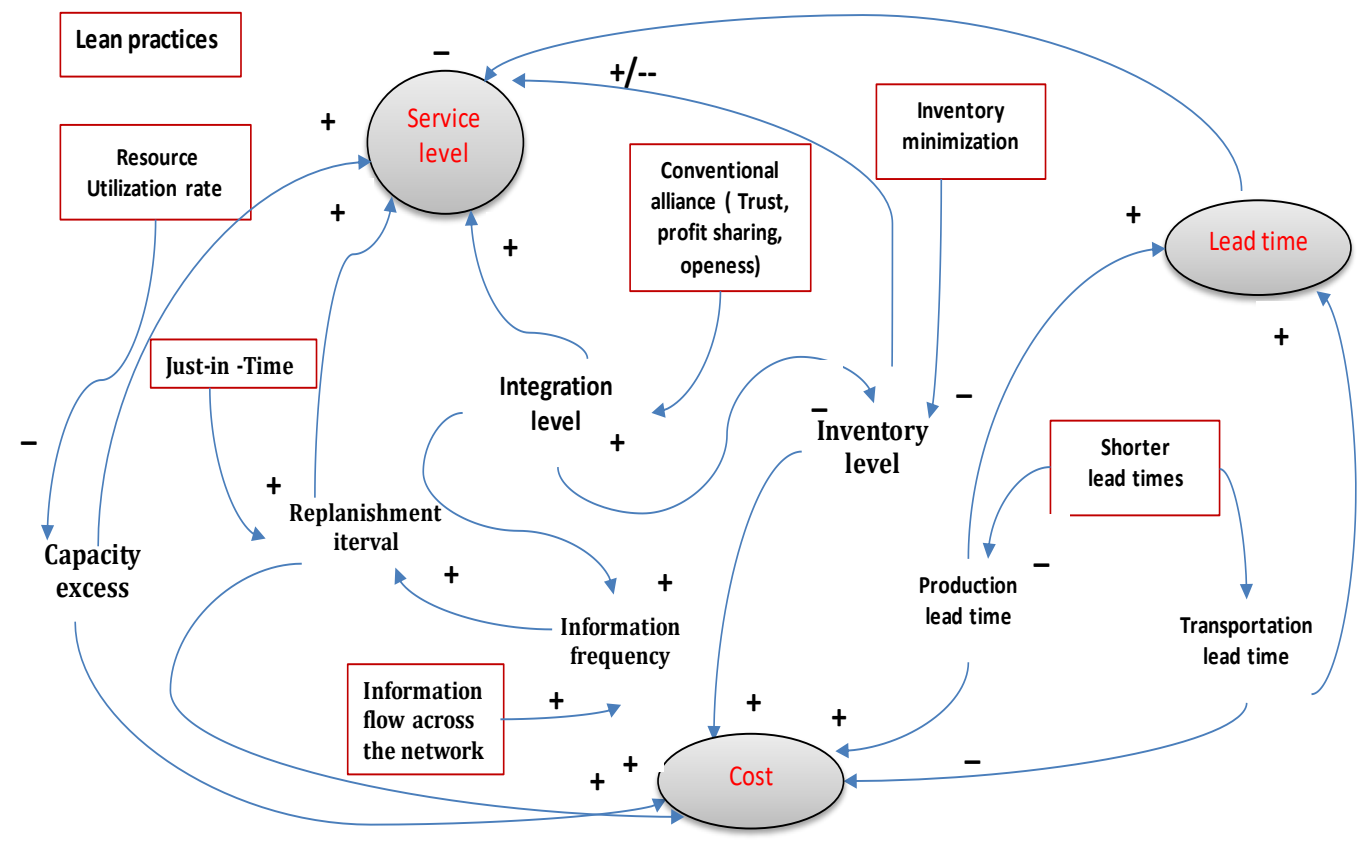

Figure 2. Lean inventory attributes and supply chain performance relationships

\subsection{Agile Inventory (Safety Buffer) Attributes vs. Supply Chain Attributes}

The link between agile inventories (safety buffer) attributes and SCP have depicted in Figure 3.

The relationship between inventory attributes and the SCP can be understood as under.

- The response of inventory in customer demand: The consequence of inventory level is affected negatively by the customer demand. Let us consider an example that the inventory is designed for better response of customer demands, then lower level of inventory is expected and the supplier readiness such as flexibility, speed and quality assurance accordingly. The readiness has a high level of speed, flexibility, and quality but the necessity of inventory is low, which gives low inventory level.

- Information frequency: The information frequency is positively elevated by an increase in visibility of the overall supply chain.

- Dynamic alliances: The magnitude of integration level is affected positively to the presence of a dynamic alliance. 
International Journal of Mathematical, Engineering and Management Sciences

Vol. 4, No. 4, 870-881, 2019

https://dx.doi.org/10.33889/IJMEMS.2019.4.4-069

- Respond speedily to customer demand: The frequency of replenishment can be enhanced by adopting a strategy of responding speedily to customer needs.

- Capacity excess: The agile inventory attributes explain the availability of a capacity excess of resources in the supply chain gives an increase in capacity surplus.

- Lead time reduction: The length of the lead time is a key factor of production lead time and transportation lead time. Lead time reduction results negative PTLT. Increasing the lead time reduction level results a decrease in production lead time as well as transportation lead time.

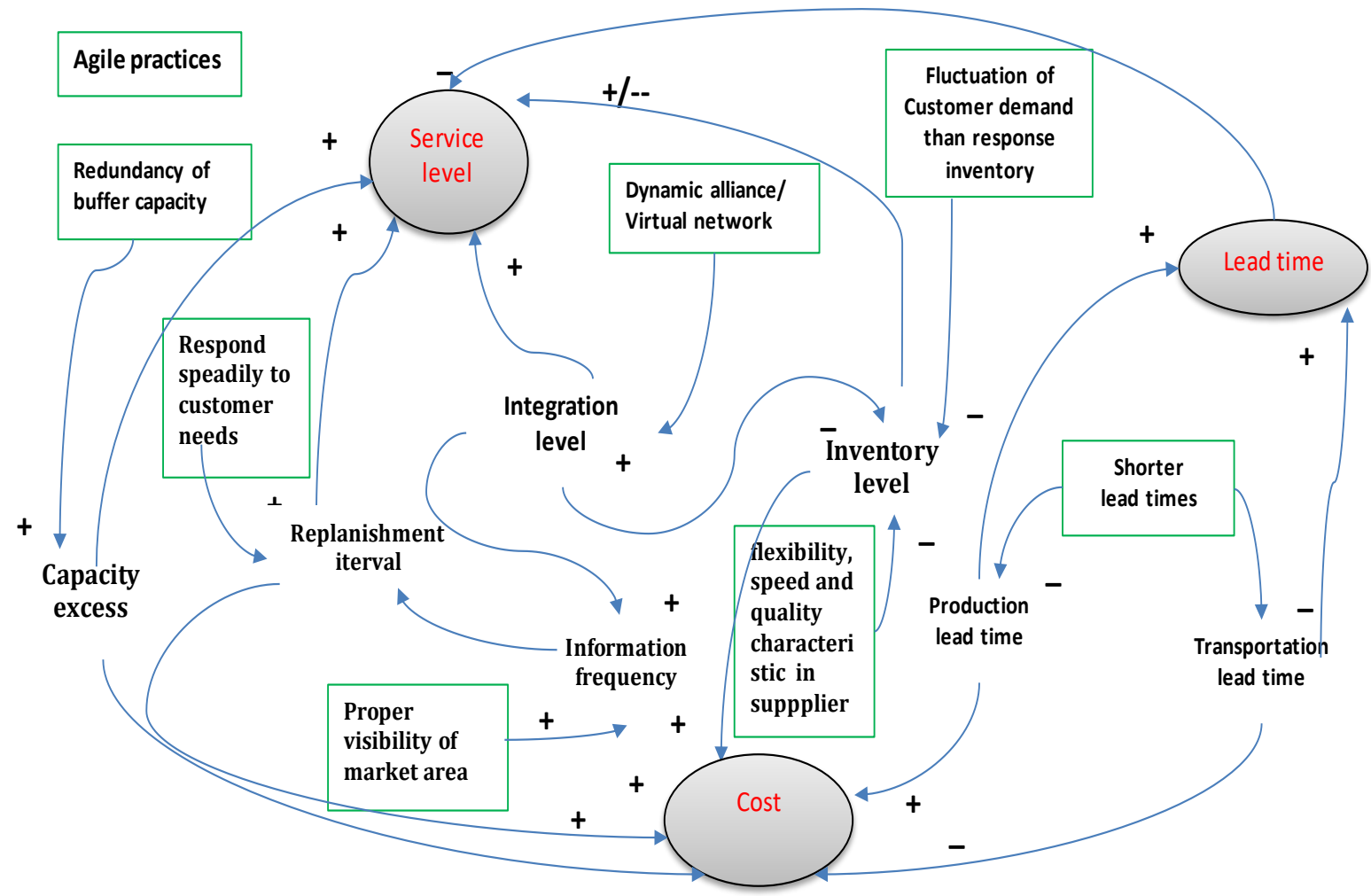

Figure 3. Agile inventory attributes and supply chain performance relationships

\section{Combined Lean and Agile Inventory Attributes Practices vs. Supply Chain Attributes}

From the required knowledge, the integration of the lean and agile inventory attributes and SCP relationships were developed and as shown in Figure 4.

From the cause diagram, to verify that most of the supply chain attributes have positive effects by all inventory attributes. Table 1 gives results of an inspection of important synergies and divergences among the lean and agile inventory attributes under study. For the implementation of 
International Journal of Mathematical, Engineering and Management Sciences

Vol. 4, No. 4, 870-881, 2019

https://dx.doi.org/10.33889/IJMEMS.2019.4.4-069

these lean and agile inventories attributes like integration level, information frequency, production lead time and transportation lead time should be managed. In such a case, the impact of all inventory attributes implementation in the characteristics magnitude may be varied.

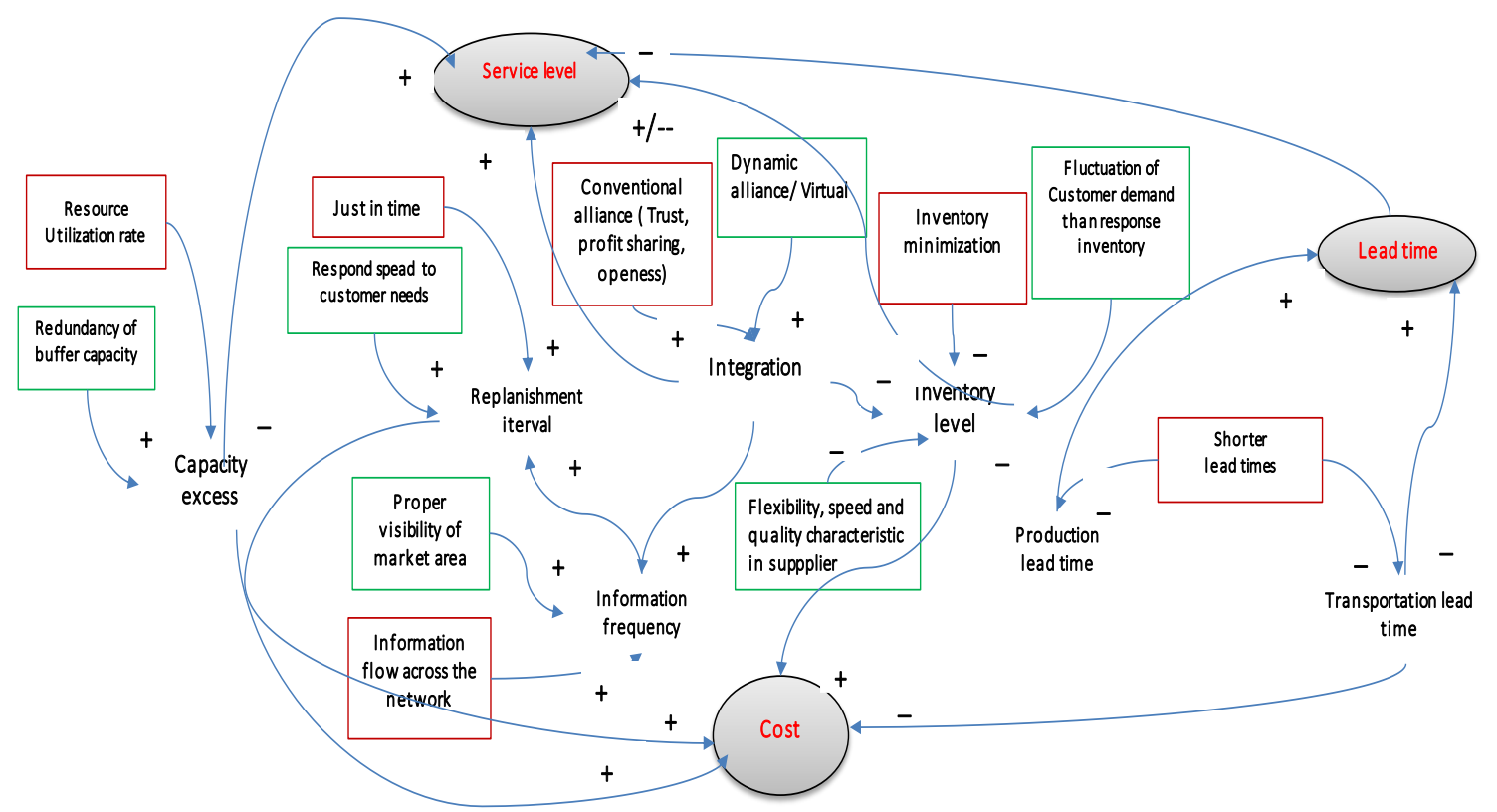

Figure 4. Conceptual model with lean and Agile inventory attributes relationship

Table 1. Lean and agile SCM synergies and divergences overview

\begin{tabular}{|c|c|c|}
\hline $\begin{array}{r}\text { Inventory Attributes } \\
\text { Performance }\end{array}$ & Lean Inventory Attributes & Agile Inventory Attributes \\
\hline Supply Chain Attributes & Increase $(\uparrow)$ & Increase $(\uparrow)$ \\
\hline Information sharing frequency & Increase $(\uparrow)$ & Increase $(\uparrow)$ \\
\hline Integration level & Decreases $(\downarrow)$ & Decreases $(\downarrow)$ \\
\hline Production lead time & Decreases $(\downarrow)$ & Decreases $(\downarrow)$ \\
\hline Transportation lead time & Decreases $(\downarrow)$ & Decreases $(\uparrow)$ \\
\hline Capacity surplus & Increase $(\uparrow)$ \\
\hline Inventory level & Decreases $(\downarrow)$ & \\
Replenishment frequency & Increase $(\uparrow)$ & \\
\hline Legend: $\uparrow$ increase; $\downarrow$ decrease & \multicolumn{2}{|c|}{} \\
\hline
\end{tabular}

Finally, conclude that cause and effect analysis under lean and agile inventory attributes impact on SCP in terms of lead time, cost and service. It has illustrated in Figure 5. 
International Journal of Mathematical, Engineering and Management Sciences

Vol. 4, No. 4, 870-881, 2019

https://dx.doi.org/10.33889/IJMEMS.2019.4.4-069

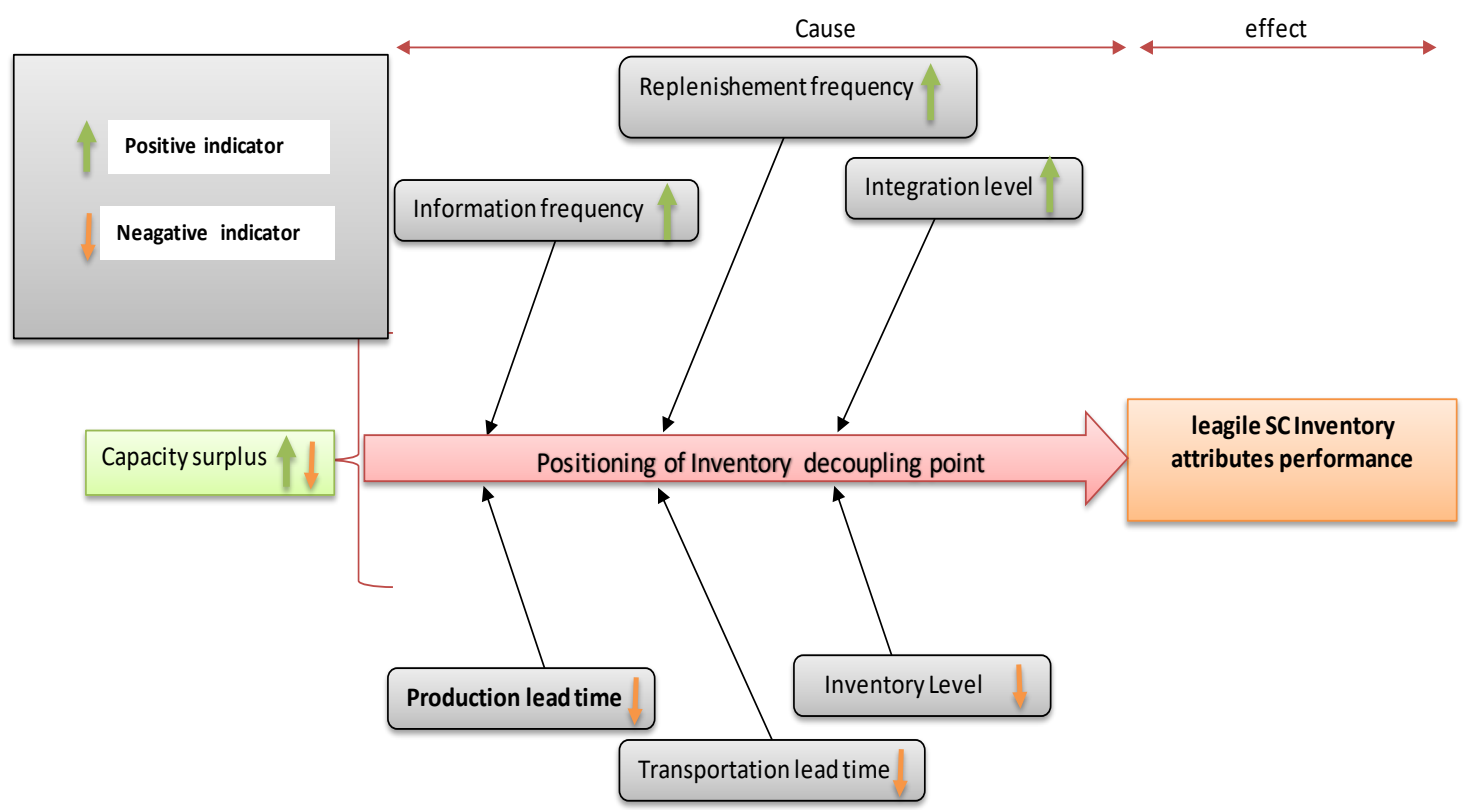

Figure 5. Leagile SC inventory attribute cause and effect analysis

It reveals that positive and negative indicators are directly impacted of integrated LASC inventory attributes performance. The accurate positioning of the decoupling point is necessary for stocking the inventory for market nature and better service for the customer. The positive indicators are such as information frequency, replenishment frequency, and integration level. The negative indicators are such as lead time (production and Transportation) and inventory level. Hence, it is necessary to balance between the lean and agile practices implementation, considering the strategy defined by the supply chain.

The key assessment of the paper to acknowledge the tools of supply chain management can be analysed. The result of assessing the lean and agile supply chain management concepts shows that the tools used in these systems can help in reducing the risk level. The concept of lean and agile inventory attributes to overcome global competitive cost reduction opportunity.

\section{Conclusions}

The conceptual model constructs and primary level knowledge of outlook of the trade-off between upstream lean inventory attributes and downstream agile inventory attributes characteristics and positioning of stocking point or surplus inventory location for decoupling point decides by managerial as good practitioners.

Cause-effect analysis demonstrated that supply chain attributes are positive or negative linkage to all lean and agile inventory attributes creates synergies among them. Lean and agile inventory attributes were found to significant effect on inventory attributes like increase in information frequency, increase in integration level, reduction in production lead time as well as in transportation lead time. In managerial point of view, cause and effect diagram provides a proactive understanding to positive and negative inventory attributes affects the SCP. 
International Journal of Mathematical, Engineering and Management Sciences

Vol. 4, No. 4, 870-881, 2019

https://dx.doi.org/10.33889/IJMEMS.2019.4.4-069

This study raises propositions of relationships between variables involving the supply chain, though only in theoretical terms, however, does not provide any empirical results. In future research, these relationships can be empirically validated. Figures 2 and 3 attempts to present the "positive" and "negative" aspects, however, there is no in-depth discussion about said aspects in light of the literature. In future research, detailed analysis with the depth discussion in light of the literature can be made.

Further, how the LASC will affect inventory attributes as well as SCP may be tested empirically. Finally, it will be interesting to know that how different business tools such as ERP and MRP-I, MRP-II can enhance the performance of SCP.

\section{Conflict of Interest}

There is no conflict of interest among the authors.

Acknowledgement

Authors would be like to thank Editor-in-Chief, Editors and anonymous reviewers.

\section{References}

Agarwal, A., Shankar, R., \& Tiwari, M.K. (2007). Modeling agility of supply chain. Industrial Marketing Management, 36(4), 443-457.

Azevedo, S.G., \& Machado, V C. (2009). Modeling lean and green performance: a manufacturing and supply chain context. International Journal of Production Economics Manuscript Draft, (IJPE-D-0900946).

Azevedo, S.G., \& Machado, V.C. (2009). Modeling lean and green performance: a manufacturing and 345 supply chain context. International Journal of Production Economics, Manuscript Draft, (IJPE-D-09346 00946).

Azevedo, S.G., Carvalho, H., Cruz-Machado, V., \& Grilo, F. (2010, September). The influence of agile and resilient practices on supply chain performance: an innovative conceptual model proposal. In Hamburg International Conference of Logistics (pp. 273-281).

Bruce, M., Daly, L., \& Towers, N. (2004). Lean or agile: a solution for supply chain management in the textiles and clothing industry?. International Journal of Operations \& Production Management, 24(2), 151-170.

Carvalho, H., Azevedo, S.G., \& Cruz-Machado, V. (2010). Supply chain performance management: lean and green paradigms. International Journal of Business Performance and Supply Chain Modelling, 2(3-4), 304-333.

Christopher, M., \& Towill, D.R. (2000). Supply chain migration from lean and functional to agile and customised. Supply Chain Management: An International Journal, 5(4), 206-213.

Katayama, H., \& Bennett, D. (1999). Agility, adaptability and leanness: a comparison of concepts and a study of practice. International Journal of Production Economics, 60, 43-51.

Khalili, J., \& Alinezhad, A. (2018). Performance evaluation in green supply chain using BSC, DEA and data mining. International Journal of Supply and Operations Management, 5(2), 182-191. 
International Journal of Mathematical, Engineering and Management Sciences

Vol. 4, No. 4, 870-881, 2019

https://dx.doi.org/10.33889/IJMEMS.2019.4.4-069

Mason-Jones, R., \& Towill, D.R. (1999). Total cycle time compression and the agile supply chain. International Journal of Production Economics, 62(1-2), 61-73.

Mason-Jones, R., Naylor, B., \& Towill, D. R. (2000). Lean, agile or leagile? Matching your supply chain to the marketplace. International Journal of Production Research, 38(17), 4061-4070.

Naylor, J. B., Naim, M. M., \& Berry, D. (1999). Leagility: integrating the lean and agile manufacturing paradigms in the total supply chain. International Journal of Production Economics, 62(1-2), 107-118.

Olhager, J. (2003). Strategic positioning of the order penetration point. International journal of production economics, 85(3), 319-329.

Pakdil, F., \& Leonard, K.M. (2014). Criteria for a lean organisation: development of a lean assessment tool. International Journal of Production Research, 52(15), 4587-4607.

Pavlis, N.E., Moschuris, S.J., \& Laios, L.G. (2018). Supply management performance and cash conversion cycle. International Journal of Supply and Operations Management, 5(2), 107-121.

Power, D.J., Sohal, A.S., \& Rahman, S.U. (2001). Critical success factors in agile supply chain management-An empirical study. International Journal of Physical Distribution \& Logistics Management, 31(4), 247-265.

Qamar, A., Hall, M. A., \&Collinson, S. (2018). Lean versus agile production: flexibility trade-offs within the automotive supply chain. International Journal of Production Research, 56(11), 3974-3993.

Routroy, S., \& Kodali, R. (2005). Differential evolution algorithm for supply chain inventory planning. Journal of Manufacturing Technology Management, 16(1), 7-17.

Sangari, M.S., Razmi, J., \& Zolfaghari, S. (2015). Developing a practical evaluation framework for identifying critical factors to achieve supply chain agility. Measurement, 62, 205-214.

Tannous, K.A., \& Yoon, S. (2018). Summarizing risk, sustainability and collaboration in global supply chain management. International Journal of Supply and Operations Management, 5(2), 192-196.

Vinodh, S., \& Aravindraj, S. (2013). Evaluation of leagility in supply chains using fuzzy logic approach. International Journal of Production Research, 51(4), 1186-1195.

Weinstein, A. (2018). Superior customer value: finding and keeping customers in the now economy. Routledge.

Womack, J.P., Jones, D.T., and Roos, D., (1990). The machine that changed the world: the story of lean production. New York: Rawson Associates.

Wu, S., \& Wee, H.M. (2009, June). How lean supply chain effects product cost and quality-A case study of the Ford Motor company. In 2009 6th International Conference on Service Systems and Service Management (pp. 236-241). IEEE.

Wyton, P., \& Payne, R. (2014). Exploring the development of competence in Lean management through action learning groups: a study of the introduction of Lean to a facilities management function. Action Learning: Research and Practice, 11(1), 42-61. 
International Journal of Mathematical, Engineering and Management Sciences

Vol. 4, No. 4, 870-881, 2019

https://dx.doi.org/10.33889/IJMEMS.2019.4.4-069

\section{Annexure-A}

Table A1. Migratory model summarising the transition in PC supply chain operations

\begin{tabular}{l|l|l|l|l}
\hline $\begin{array}{l}\text { Supply chain } \\
\text { evolution phase }\end{array}$ & Phase I & Phase II & Phase III & Phase IV \\
\hline $\begin{array}{l}\text { Supply chain time } \\
\text { decade }\end{array}$ & Early 1980s & Late 1980s & Early 1990s & Late 1990s \\
\hline $\begin{array}{l}\text { Market supply } \\
\text { chain philosophy }\end{array}$ & Product driven & Market orientated & Market driven & Customer driven \\
\hline Supply Chain type & $\begin{array}{l}\text { Lean functional } \\
\text { silos }\end{array}$ & Lean supply chain & $\begin{array}{l}\text { Leagile supply } \\
\text { chain }\end{array}$ & $\begin{array}{l}\text { Customised leagile } \\
\text { supply chain }\end{array}$ \\
\hline Market winner & Quality & Cost & Availability & Lead time \\
\hline Market qualifiers & $\begin{array}{l}\text { Cost lead } \\
\text { Availability ,lead } \\
\text { time }\end{array}$ & $\begin{array}{l}\text { Availability } \\
\text { time, quality } \\
\text { quality, cost }\end{array}$ & $\begin{array}{l}\text { Quality, } \\
\text { Availability }\end{array}$ \\
\hline $\begin{array}{l}\text { Performance } \\
\text { metrics }\end{array}$ & $\begin{array}{l}\text { Stock turns, } \\
\text { production cost }\end{array}$ & $\begin{array}{l}\text { Throughput time , } \\
\text { physical cost }\end{array}$ & $\begin{array}{l}\text { Market share, } \\
\text { Total cost }\end{array}$ & $\begin{array}{l}\text { Customer } \\
\text { satisfaction, Value } \\
\text { added }\end{array}$ \\
\hline
\end{tabular}

Source: Christopher and Towill (2000) 
International Journal of Mathematical, Engineering and Management Sciences

Vol. 4, No. 4, 870-881, 2019

https://dx.doi.org/10.33889/IJMEMS.2019.4.4-069

Table A2. Difference between lean, agile and leagile supply chain

\begin{tabular}{|c|c|c|c|}
\hline $\begin{array}{l}\text { Distinguishing } \\
\text { attributes }\end{array}$ & Lean supply chain & Agile supply chain & Leagile supply chain \\
\hline Market demand & Predictable & Volatile & Volatile and unpredictable \\
\hline Product variety & Low & High & Medium \\
\hline Product life cycle & Long & Short & Short \\
\hline Customer drivers & Cost & $\begin{array}{l}\text { Lead-time } \\
\text { availability }\end{array}$ & Service level \\
\hline Profit margin & Low & High & Moderate \\
\hline Dominant costs & Physical costs & Marketability costs & Both \\
\hline Stock out penalties & $\begin{array}{ll}\text { Long } & \text { term } \\
\text { contractual } & \end{array}$ & Immediate and volatile & No place for stock out \\
\hline Purchasing policy & Buy goods & Assign capacity & Vendor managed inventory \\
\hline Information enrichment & Highly desirable & Obligatory & Essential \\
\hline Forecast mechanism & Algorithmic & Consultative & Both/either \\
\hline Typical products & Commodities & Fashion goods & $\begin{array}{l}\text { Product as per customer } \\
\text { demand }\end{array}$ \\
\hline Lead time compression & Essential & Essential & Desirable \\
\hline Eliminate muda & Essential & Desirable & Arbitrary \\
\hline Rapid reconfiguration & Desirable & Essential & Essential \\
\hline Robustness & Arbitrary & Essential & Desirable \\
\hline Quality & Market qualifier & Market qualifier & Market qualifier \\
\hline Cost & Market winner & Market qualifier & Market winner \\
\hline Lead-time & Market qualifier & Market qualifier & Market qualifier \\
\hline Service level & Market qualifier & Market winner & Market winner \\
\hline
\end{tabular}

Sources: Naylor et al. (1999), Mason-Jones et al. (2000), Olhager (2003), Bruce et al. (2004) 